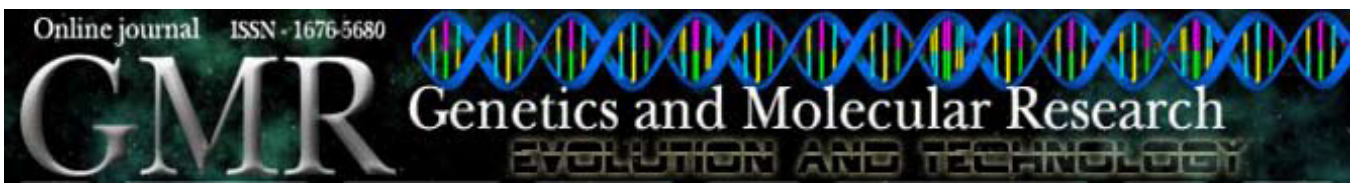

\title{
Genetic control of the resistance of common beans to white mold using the reaction to oxalic acid
}

\author{
R.P. Antonio, J.B. Santos, T.P. Souza and F.F. Carneiro \\ Departamento de Biologia, Universidade Federal de Lavras, Lavras, MG, Brasil \\ Corresponding author: J.B. Santos \\ E-mail: jbsantos@ufla.br
}

Genet. Mol. Res. 7 (3): 733-740 (2008)

Received April 7, 2008

Accepted July 4, 2008

Published August 14, 2008

\begin{abstract}
The use of genetically resistant cultivars is the best method to reduce losses caused by white mold (Sclerotinia sclerotiorum (Lib.) de Bary). As the best known resistance sources are not adapted, the genetic control of white mold in the common bean must be understood to guide breeding more efficiently. The objective of the present study was to identify the genetic control of the resistance of common bean to white mold by an indirect method using oxalic acid. For this, the descendents of the VC3 cross (susceptible) x G122 (resistant) were used. The trait was assessed by a descriptive key of scores after treatment with oxalic acid. The assessments were made on individual plants $\left(\mathrm{P}_{1}, \mathrm{P}_{2}, \mathrm{~F}_{1}, \mathrm{~F}_{2}\right.$ populations and within $\mathrm{F}_{2: 3}$ families) in a complete randomized design and on family means where the randomized block design was used with two replications. The oxalic acid method was efficient in detecting genetic differences. The additive effects dominated and genetic control was characterized by partial dominance $(\mathrm{d} / \mathrm{a}=0.47)$. At least one resistance gene is involved, although the trait is greatly influenced by the environment. The broad sense heritability at the family mean level $(0.47)$ was greater than that obtained at the individual plant level (0.33), indicating that selection should be more efficient based on progeny mean assessments.
\end{abstract}

Key words: Sclerotinia sclerotiorum; Phaseolus vulgaris;

Oxalic acid; Physiological resistance 


\section{INTRODUCTION}

White mold (Sclerotinia sclerotiorum (Lib.) de Bary) in common bean is a serious disease, especially in winter cropping under irrigation using a central pivot. The climate conditions in the contaminated areas favorable to its development are moisture and cool temperatures. In this situation, a common bean farm can have average losses of $30 \%$ or more, and they can reach $100 \%$ in rainy periods when preventive measures are not taken (Oliveira, 2005). Several control procedures have been suggested to limit losses due to white mold, but the use of genetically resistant cultivars is the best method to reduce the risks of epidemics (Castaño et al., 2001). However, it is difficult to implement because most of the cultivars available on the market are highly susceptible. Sources of genetic resistance to the pathogen are restricted to some exotic cultivars, which are not adapted to Brazil and which have potential use in breeding programs but cannot be used directly by the producers. For common bean breeding, the transfer of a resistant allele is not enough, the cultivars need to be superior in several agronomic traits. Some characteristics such as grain color, size and shine influence commercialization. Average opaque grains weighing 23 to $25 \mathrm{~g}$ are more accepted than shiny grains (Aidar, 2003). Upright stand makes crop management easier and contributes to preventing white mold. In addition to the stand, there is information on the resistance of the plant, also known as physiological resistance, which is polygenic in nature (Miklas et al., 2001). There are several methods to detect physiological resistance to white mold in the common bean (Hunter et al., 1981; Miklas et al., 1992a,b; Petzoldt and Dickson, 1996; Steadman et al., 1997). Most of these tests use a limited number of genotypes and depend on the fungal mycelia in the assessments (Kolkman and Kelly, 2000), which are influenced by the variability of the isolates (Miklas et al., 1992a; Pratt and Rowe, 1995) and the sensitivity of the pathogen to high temperatures (Boland and Hall, 1987). All these factors limit the assessment methods in greenhouses using the pathogen. The evidence that $S$. sclerotiorum uses oxalic acid to invade the common bean plant led to the development of an indirect assessment method of resistance based on the plant reaction when placed in oxalic acid solution without root (Kolkman and Kelly, 2000). An advantage of this procedure is the identification of physiological resistance without interference from other resistance mechanisms. Thus, the objective of the present study was to identify the common bean genetic control of resistance to white mold indirectly using the reaction to oxalic acid.

\section{MATERIAL AND METHODS}

The exotic G122 line, resistant to white mold, was crossed with the adapted and susceptible VC3 line. This line has Carioca grain type, bush stand, resistance to some races of $C$. lindemuthianum and high yield. A total of 80 plants were assessed for each parent, 20 from $\mathrm{F}_{1}, 300 \mathrm{~F}_{2}$ plants and $173 \mathrm{~F}_{2: 3}$ families. $\mathrm{F}_{1}$ and $\mathrm{F}_{2}$ were assessed in plots with 10 plants, with 2 replications, in a complete randomized design. Fifteen plots were used per $\mathrm{F}_{2}$ replication. Each $\mathrm{F}_{2: 3}$ family was assessed in a plot with 10 plants with 2 replications, in 8 stages. At each stage, the parents were used with common controls in plots with 5 plants and 2 replications. All plants were assessed individually, without roots, in a solution of $20 \mathrm{mM}$ oxalic acid (Kolkman and Kelly, 2000). A descriptive key of scores (from 1 without symptoms to 6 representing completely wilted plants), used by the cited authors, was employed to assess each plant after 
16-22 $\mathrm{h}$ in the solution, starting at 5:00 pm. Initially, an analysis of variance among $\mathrm{F}_{2: 3}$ family means was set up, using the augmented block design with 2 replications. The means were adjusted based on the controls used at each stage of the assessment, because it was not possible to assess all $\mathrm{F}_{2: 3}$ families in a single conventional experiment. Next, an analysis of variance using the adjusted means was carried out as a randomized block design with 2 replications. The variances among parent, $\mathrm{F}_{1}, \mathrm{~F}_{2}$ and within $\mathrm{F}_{2: 3}$ family plants were used to estimate the components of variance (Vencovsky and Barriga, 1992; Ramalho et al., 1993). The score means of the $\mathrm{F}_{1}, \mathrm{~F}_{2}, \mathrm{~F}_{2: 3}$ population and the two parents were used to estimate the mean components. The additive and dominant model without epistasis was considered using the Mapgen program (Ferreira and Zambalde, 1997).

The fit of the model for both the mean components and for the components of variance was assessed by the coefficient of determination $\left(\mathrm{R}^{2}\right)$ and the chi-square test $\left(\chi^{2}\right)$. Broad sense heritability $\left(\mathrm{ha}^{2}\right)$ and narrow sense heritability $\left(\mathrm{hr}^{2}\right)$ at the plant level and broad sense heritability $\left(\mathrm{h} \alpha^{2}\right)$ at the $\mathrm{F}_{2: 3}$ family mean were assessed according to Ramalho et al. (1993). The expressions of Knapp et al. (1985) were used to estimate the confidence intervals of the heritability at the individual level. The number of genes $(k)$ involved was estimated using the expression of Wright (1934).

\section{RESULTS AND DISCUSSION}

\section{Use of individual plant means and variances}

The oxalic acid method was efficient in detecting genetic differences between the resistant and susceptible parents $(\mathrm{P} \leq 0.01)$ in response to oxalic acid (Table 1). The G122 line scored 1.58 on average and the VC3 cultivar scored 3.14 on average. Kolkman and Kelly (2000) also reported the resistance of the G122 line to oxalic acid at temperatures similar to the present study (average of $21^{\circ} \mathrm{C}$ ). However, they reported that high temperatures $\left(24^{\circ}\right.$ to $40^{\circ} \mathrm{C}$ ) affected the resistance of the line. The authors also noted that this physiological resistance mechanism is specific and may be associated with other mechanisms, such as bush stand, to show greater levels of resistance to the pathogen. The summary of the analysis of variance of the reaction score of the individual plants in the oxalic acid test and the differences among the means of the $\mathrm{F}_{1}, \mathrm{~F}_{2}$, and parents are shown in Table 2. The population effect was highly significant, showing the existence of genetic variability among them $(\mathrm{P}<0.01)$. Although high genetic difference was detected among the populations, there was a high coefficient of variation, the trait was consequently sensitive to several factors, especially those that affect young plant development before treatment with the acid like the temperature and adaptation of the genotype. Kolkman and Kelly (2000) reported coefficients of variation from 14.10 to 20.30, in a study of the effect of oxalic acid on the common bean, at controlled temperatures. Table 3 shows the average scores of the populations assessed and the estimates of the mean components. The data fitted the dominant additive model, with $\mathrm{R}^{2}$ being practically $100 \%$, although the chi-square result was significant. The additive effects presented a highly significant negative value $(\mathrm{P}<0.01)$. Their magnitude was 2 -fold greater than the effects of dominance, suggesting a great contribution to resistance to oxalic acid and the pathogen. The genetic effects of dominance, represented by the $d$ component, which measures the deviation of the heterozygote from the mean, was significantly different from zero and negative. Therefore, the effects 
of dominance are in the direction of reducing the wilting caused by oxalic acid, that is, it also confers resistance to the pathogen. However, this component was less significant $(\mathrm{P}<0.05)$.

Table 1. Summary of the analyses of variance of scores of the oxalic acid test among parent genotype.

\begin{tabular}{lcc}
\hline Source of variation & d.f. & Mean square \\
\hline Between & 1 & $97.656^{*}$ \\
Within & 158 & 0.918 \\
CV (\%) & & $40.66 \%$ \\
Mean & & 2.36
\end{tabular}

d.f. = degrees of freedom; $\mathrm{CV}=$ coefficient of variation.

$*$ Significant at $1 \%$ probability by the $\mathrm{F}$ test.

\begin{tabular}{|c|c|c|}
\hline Source of variation & d.f. & Mean square \\
\hline Replications & 1 & 17.1125 \\
\hline Treatment & 3 & $20.0656 *$ \\
\hline Error & 3 & 2.2064 \\
\hline Within $P_{1}$ & 78 & 0.5765 \\
\hline Within $P_{2}$ & 78 & 1.1259 \\
\hline Within $\mathrm{F}_{1}$ & 18 & 0.1974 \\
\hline Within $\mathrm{F}_{2}$ & 298 & 1.1536 \\
\hline CV (\%) & & 48.80 \\
\hline Mean & & 2.23 \\
\hline
\end{tabular}

d.f. = degrees of freedom; $\mathrm{CV}=$ coefficient of variation

*Significant at $1 \%$ probability by the $\mathrm{F}$ test.

Table 3. Means and variances of the populations assessed and their respective estimates for the trait common bean reaction to oxalic acid obtained for the $\mathrm{G} 122 \mathrm{x}$ VC 3 cross.

\begin{tabular}{lccc}
\hline Population & & Means & Variance \\
\cline { 2 - 4 } & Observed & Expected & 0.5765 \\
\hline $\mathrm{G} 122$ & 1.58 & 1.40 & 1.1259 \\
$\mathrm{VC} 3$ & 3.14 & 3.14 & 0.2056 \\
$\mathrm{~F}_{1}$ & 1.25 & 1.40 & 1.1283 \\
$\mathrm{~F}_{2}$ & 2.02 & 2.14 & 0.9651 \\
$\mathrm{~F}_{3}$ & 2.52 & 2.51 & Mean components \\
\hline Parameter & & Standard errors & $\mathrm{P}>|\mathrm{T}|$ \\
\cline { 2 - 4 } & Estimate & 0.08 & 0.0008 \\
\hline $\mathrm{m}$ & 2.88 & 0.29 & 0.0085 \\
$\mathrm{a}$ & -3.14 & 0.20 & 0.0184 \\
$\mathrm{~d}$ & -1.48 & & 0.0046 \\
$\chi^{2} / \mathrm{a}$ & 0.47 & & - \\
$\mathrm{R}^{2}(\%)$ & 10.75 & & \\
\hline
\end{tabular}

$\mathrm{m}=$ mean score estimate; $\mathrm{a}=$ additive effects; $\mathrm{d}=$ dominance effects; $\mathrm{d} / \mathrm{a}=$ mean degree of dominance; $\chi^{2}=$ chisquare test; $\mathrm{R}^{2}=$ coefficient of determination. 
The mean of the parents was 2.35 (Table 1) clearly higher than the $\mathrm{F}_{1}$ mean (Table 3), while the $\mathrm{F}_{2}$ mean (Table 3) was intermediate between the mean of the parents and the $\mathrm{F}_{1}$, characterizing partial dominance. The magnitudes of these means were compatible with the mean degree of dominance $(\mathrm{d} / \mathrm{a}=0.47)$. The predominance of the additive effect was also reported in colza and sunflowers in the control of the development of the lesion in the canopy caused by S. sclerotiorum (Baldini et al., 2004; Zhao et al., 2004). Also in sunflowers, using S. sclerotiorum mycelia (Castaño et al., 2001), all estimates were significantly different from zero, and the additive effect $(\mathrm{a}=-0.34 \pm 0.08)$ was negative and highly significant. The genetic effects of dominance were also negative $(d=-0.39 \pm 0.23)$ and tended to reduce the lesion areas. Its magnitude was very similar to the additive effects, but of less importance.

This comparison showed that indirect assessment by oxalic acid is in line with the assessments with fungal mycelia and can be used in assessments of resistance to white mold. The effects of dominance and its epistasis interactions are less important in self-pollinating species (Brim and Cockerham, 1961). The breeding techniques that benefit from high additive variance and the additive $\mathrm{x}$ additive interaction to obtain genetic gains are very important in common bean breeding, because this is a self-pollinating species. As the additive effects were significant in this study, the predicted gains for resistance of the common bean to oxalic acid produced by $S$. sclerotiorum can be reached.

The fit to the model was suitable $\left(\mathrm{R}^{2}=98.67 \%\right)$ for the estimates of the components of variance (Table 4), although $\chi^{2}$ was also significant. The variance of dominance was of much lower magnitude compared to the additive variance. The ratio was 11:1, although the error associated with the estimate was much greater than the estimates of the mean components, as usually occurs with variances. Especially in this study, the environmental variance among plants was very high in the susceptible parents (VC3), highlighting the sensitivity of the trait to the environment. Thus, the difficulty in selecting resistant plants in segregant populations can be understood. Therefore, the breeder should choose to assess progenies with a greater number of plants, when greater gain with selection is expected. The estimates of broad and narrow sense heritability were 0.33 and 0.30 , respectively. The heritability values, although of low magnitude, were sufficient to suggest that resistance can be effectively selected by the oxalic acid method. The magnitudes of these estimates were similar to those reported by Kim and Diers (2000) who estimated heritability in $\mathrm{F}_{3}$-derived populations $\left(\mathrm{ha}^{2}=0.30\right.$ to 0.71$)$ for a disease severity index. In the three populations derived from the Andean line (G122) hr ${ }^{2}$ estimates for disease severity index ranged from 0.65 (straw test) to 0.78 (field test) (Miklas et al., 2001; Park et al., 2001). In green beans, the estimates ranged from 0.6 (field test) to 0.73 (straw test) (Miklas et al., 2003). The heritability estimates for resistance to white mold suggested that the heritability for the trait is influenced by the parent genotype, procedures used in the test, disease severity at assessment and interaction of environmental and agronomic factors. It was also observed that only one resistance gene is involved. However, according to Ramalho et al. (1993), it is very difficult to determine the number of genes precisely, mainly because of the environmental effect on the manifestation of the traits, as in the present study. A QTL with a relatively large effect (around 38\%) detected by Miklas et al. (2001) is in line with this estimate. However, it is known that the genetic control of white mold in the field is quantitative and greatly influenced by the environment (Castaño et al., 1993). This is why in this condition there is a combination of other resistance mechanisms, such as avoidance of the disease because of the more bush stand, which reduces excess moisture among the plants, in 
addition to genetic mechanisms not due to oxalic acid but related to the defense of the plant against S. sclerotiorum.

Table 4. Estimates of variance components for the trait common bean reaction to oxalic acid obtained for the
G122 x VC3 cross, from individual plant data.
\begin{tabular}{lccccc}
\hline Parameter & \multicolumn{5}{c}{ Variance components } \\
\cline { 2 - 5 } & Estimate & Error & LL & UL & P $>|T|$ \\
\hline$V_{A}$ & 0.3474 & 0.2169 & 0.2904 & 0.4231 & 0.2505 \\
$V_{D}$ & 0.0300 & 0.4983 & 0.0268 & 0.0340 & 0.9574 \\
$V_{E}$ & 0.7763 & 0.1908 & 0.6763 & 0.9004 & 0.0555 \\
$V_{B}$ & 0.0000 & 0.0000 & 0.0000 & 0.0000 & - \\
$\chi^{2}$ & 16.73 & & & & 0.0002 \\
$R^{2}(\%)$ & 98.67
\end{tabular}

$\mathrm{LL}=$ lower limit; $\mathrm{UL}=$ upper limit; $\mathrm{V}_{\mathrm{A}}=$ genetic variance of the additive effects; $\mathrm{V}_{\mathrm{D}}=$ genetic variance of the effects of dominance; $\mathrm{V}_{\mathrm{E}}=$ environmental variance; $\mathrm{V}_{\mathrm{B}}=$ environmental variance among $\mathrm{F}_{2: 3}$ family means.

\section{Variances among $F_{2: 3}$ family means}

The analysis of variance of the scores given to the oxalic acid reaction trait of common bean, in the $\mathrm{F}_{2: 3}$ families, is shown in Table 5 . The coefficient of variation was $25.18 \%$, which is much smaller than the estimates obtained with individual plants (Tables 1 and 2) and similar to those reported by Kolkman and Kelly (2000). In principle, this result showed greater efficiency in the assessment, considering progeny mean. A significant genetic difference was detected among families $(\mathrm{P}<0.01)$. Broad sense heritability was 0.47 , with a confidence interval of 0.26 to 0.64 , superior to that obtained in individual plants ( 0.33$)$. In a similar study with lines derived from $\mathrm{F}_{3}$ of a cross between the Bunsi (Ex Rico 23) x Newport and Huron x Newport cultivars, Kolkman and Kelly (2003) reported that heritability estimates for resistance to oxalic acid were as low as $0.19(0$ to 0.37 confidence interval) which was considered low by these authors, and as high as $0.56(0.18$ to 0.73 confidence interval) which was considered moderate, respectively for the populations.

$\begin{aligned} & \text { Table 5. Analysis of variance of the trait common bean reaction to oxalic acid obtained in the evaluation of the } \\
& \text { means of the } \mathrm{F}_{2: 3} \text { families of the } \mathrm{G} 122 \times \mathrm{VC} 3 \text { cross. }\end{aligned}$
\begin{tabular}{lrc}
\hline Source of variation & d.f. & Mean square \\
\hline Replications & 1 & 0.1504 \\
Families & 132 & $0.8069^{*}$ \\
Error & 265 & 0.4241 \\
Total & & - \\
Mean & & 2.59 \\
CV (\%) & & 25.18 \\
Parameter estimates & & 0.4035 \\
Phenotypic variance & & 0.2121 \\
Environmental variance & & 0.1914 \\
Genetic variance & & 0.4744 \\
Broad sense heritability &
\end{tabular}

d.f. $=$ degrees of freedom; $\mathrm{CV}=$ coefficient of variation.

* Significant at $1 \%$ probability by the $\mathrm{F}$ test. 
Although the heritability estimates for physiological resistance were generally low or moderate (Miklas et al., 2001; Park et al., 2001), selection of resistant genotypes, such as to oxalic acid, is important to guarantee the free genetic gain of other factors, which is expected in field assessments and also to contribute to resistance, such as bush stand. In field assessments, Miklas et al. (1992a) found in derived Ex Rico 23 populations heritability estimates of moderate to high magnitude $\left(h \alpha^{2}=0.58\right.$ to 0.77$)$. According to the authors, the amplitude of these estimates was influenced by the parent genotype and interactions among environmental and agronomic factors. As resistance to white mold is greatly influenced by the environment, several assessments in different locations are recommended to guarantee the identification of more resistant lines in the segregant populations.

\section{ACKNOWLEDGMENTS}

The authors thank CNPq and CAPES for grant support, FAPEMIG for funding and FAEPE/UFLA for the use of the infrastructure.

\section{REFERENCES}

Aidair H (2003). Cultivo do Feijoeiro Comum. In: Sistemas de Produção, 2. Embrapa Arroz e Feijão, Santo Antônio de Goiás. http://sistemasdeproducao.cnptia.embrapa.br/FontesHTML/Feijao/CultivodoFeijoeiro/.

Baldini M, Vischi M, Turi M, Di Bernardo N, et al. (2004). Evaluation of genetic variability for Sclerotinia sclerotiorum Lib. de Bary resistance in an $\mathrm{F}_{2}$ population from a cross between susceptible and resistant sunflower. Helia 27: 159-170.

Boland GJ and Hall R (1987). Epidemiology of white mold of bean in Ontario. Can. J. Plant Pathol. 9: 218-224.

Brim CA and Cockerham CC (1961). Inheritance of quantitative characters in soybeans. Crop Sci. 1: 187-190.

Castaño F, Vear F and Tourvieille D (1993). Resistance of sunflower inbred lines to various forms of attack by Sclerotinia sclerotiorum and relations with some morphological characters. Euphytica 68: 85-98.

Castaño F, Vear F and Tourvieille de Labrouhe D (2001). The genetics of resistance in sunflower capitula to Sclerotinia sclerotiorum measured by mycelium infections combined with ascospore tests. Euphytica 122: 373-380.

Ferreira DF and Zambalde AL (1997). Simplificação das análises de algumas técnicas especiais da experimentação agropecuária no Mapgen e softwares correlatos. In: Anais do Congresso da Sociedade Brasileira de Informática Aplicada à Agropecuária e Agroindústria, Belo Horizonte, 285-291.

Hunter JE, Dickson MH and Cigna JA (1981). Limited-term inoculation: A method to screen bean plants for partial resistance to white mold. Plant Dis. 65: 414-417.

Kim HS and Diers BW (2000). Inheritance of partial resistance to Sclerotinia stem rot in soybean. Crop Sci. 40: 55-61.

Knapp SJ, Stroup WW and Ross WM (1985). Exact confidence intervals for heritability on a progeny mean basis. Crop Sci. 25: 192-194.

Kolkman JM and Kelly JD (2000). An indirect test using oxalate to determine physiological resistance to white mold in common bean. Crop Sci. 40: 281-285.

Kolkman JM and Kelly JD (2003). QTL conferring resistance and avoidance to white mold (Sclerotinia sclerotiorum) in common bean (Phaseolus vulgaris). Crop Sci. 43: 539-548.

Miklas PN, Grafton KF and Nelson BD (1992a). Screening for partial physiological resistance to white mold in dry bean using excised stems. J. Am. Soc. Hortic. Sci. 117: 321-327.

Miklas PN, Grafton KF, Secor GA and McClean PE (1992b). Use of pathogen filtrate to differentiate physiological resistance of dry bean to white mold disease. Crop Sci. 32: 310-312.

Miklas PN, Delorme R, Johnson WC and Gepts P (2001). QTL conditioning physiological resistance and avoidance to white mold in dry bean. Crop Sci. 41: 309-315.

Miklas PN, Delorme R and Riley R (2003). Identification of QTL conditioning resistance to white mold in snap bean. $J$. Am. Soc. Hortic. Sci. 128: 564-570.

Oliveira SHF (2005). Manejo do mofo branco. DBO Agrotecnol. 2: 8-13.

Park SO, Coyne DP, Steadman JR and Skroch PW (2001). Mapping of QTL resistance to white mold diseases in common bean. Crop Sci. 41: 1253-1262. 
Petzoldt R and Dickson MH (1996). Straw test for white mold in beans. Ann. Rep. Bean Improv. Coop. 39: 142-143.

Pratt RG and Rowe DE (1995). Comparative pathogenicity of isolates of Sclerotinia trifoliorum and S. sclerotiorum on alfalfa cultivars. Plant Dis. 79: 474-477.

Ramalho MAP, Santos JB and Zimmermann MJO (1993). Genética quantitativa em plantas autógamas: aplicações ao melhoramento do feijoeiro. Ed. da Universidade Federal de Goiás, Goiânia.

Steadman JR (1997). 1996 White mold (Sclerotinia) bean nursery summary. Annu. Rep. Bean Improv. Coop. 40: 142.

Vencovsky R and Barriga P (1992). Genética biométrica no fitomelhoramento. Sociedade Brasileira de Genética, Ribeirão Preto.

Wright S (1934). The results of crosses between inbred strains of guinea pigs, differing in number of digits. Genetics 19: 537-551.

Zhao J, Peltier AJ, Meng J, Osborn TC, et al. (2004). Evaluation of Sclerotinia stem rot resistance in oilseed Brassica napus using a petiole inoculation technique under greenhouse conditions. Plant Dis. 88: 1033-1039. 